\title{
Ostvarenje proračuna općina, gradova i županija u 2014.
}

\author{
KATARINA OTT, Institut za javne financije \\ MIHAELA BRONIĆ, Institut za javne financije
}

Cilj je ovoga rada što zornije predočiti osnovne podatke o ostvarenju proračuna hrvatskih lokalnih jedinica $u$ 20I4. Riječje o sintetiziranim tabelama koje se temelje na bazi podataka Ministarstva financija, a sadrže prihode i rashode ${ }^{2}$ te suficit ili deficit (po stanovniku i ukupno). Dodani su i podaci o broju stanovnika ${ }^{3}$ razini proračunske transparentnosti svih lokalnih jedinica. S ovim tekstom i tabelama koje se nude i u Excel formatu, čitatelji se mogu upoznati s fiskalnim stanjem svojih lokalnih jedinica, a mogu poslužiti i kao podloga za analizu pri eventualnom odlučivanju o teritorijalnoj i fiskalnoj reorganizaciji države.

Naime, pri analizi transparentnosti proračuna hrvatskih lokalnih jedinica u razdoblju od studenog 2014. do ožujka 2015., veliki je trud trebalo uložiti u prikupljanje osnovnih proračunskih podataka o lokalnim jedinicama. ${ }^{4}$ Premda Ministarstvo financija objavljuje ostvarenje proračuna svih lokalnih jedinica ${ }^{5}$, riječ je o ogromnim Excel tabelama u kojima su gradovi i općine složeni po županijama i u kojima se često zbog velikog broja lokalnih jedinica za koje su prikazani čitavi proračuni - nije lako snalaziti. Ovdje se čitateljima želi omogućiti brzi uvid u osnovno financijsko stanje lokalnih jedinica u 20I4., a podrobnije se sami mogu informirati na web stranicama Ministarstva financija i svojih lokalnih jedinica. Ipak, potrebno je nekoliko napomena za pravilno razumijevanje prikazanih podataka.

Prvo, ne smije se uspoređivati iznose županija, gradova i općina, jer županije, gradovi i općine imaju nadležnosti za prikupljanje različitih vrsta prihoda i pružanje različitih vrsta javnih dobra i usluga. Stoga, primjerice, prosječni rashod po stanovniku - županija I.o7o kuna, općina 3.082 kuna i gradova (uključen Grad Zagreb) 3.999 kuna $^{6}$ - odražava i činjenicu njihovih različitih nadležnosti. Svaki građanin može zbrojiti rashode po stanovniku svoje općine ili grada i svoje županije kako bi saznao koliko se ukupno na lokalnoj razini u prosjeku troši po stanovniku njegove općine ili grada. Iznimka je Grad Zagreb koji je istovremeno i grad i županija, te građani Zagreba trebaju gledati samo podatke za Zagreb.

\footnotetext{
${ }^{\mathrm{I}}$ U ovome tekstu naziv "lokalne jedinice” podrazumijeva sve županije, gradove i općine, a "lokalni proračuni” se odnose na proračune svih županija, općina i gradova.

${ }^{2}$ Nisu uključeni primici od financijske imovine i zaduživanja, te izdaci za financijsku imovinu i otplate zajmova.

${ }^{3}$ Prema DZS (2015).

${ }_{4}^{4}$ Rezultati te analize dostupni su u Ott, Bronić i Petrušić (2015) te na web stranici http:/ /www.ijf.hr/transparentnost/.

${ }^{5} \mathrm{Na}$ web stranicama Ministarstva financija (2015) dostupni su podaci za razdoblje 1998.-20I4.

${ }^{6}$ Budući da rashodi Zagreba iznose 9.662 kune po stanovniku, prosjek gradova bez Zagreba bio bi nešto niži, odnosno 3.954 kune.
} 
Drugo, valja imati na umu, da sâm proračun ne mora uvijek odražavati stvarno financijsko stanje lokalnih jedinica, jer se one često zadužuju preko društava ili ustanova u svom vlasništvu/suvlasništvu, a ne kroz svoj proračun.? Za utvrđivanje stvarnog financijskog stanja lokalnih jedinica, trebalo bi uz proračun raspolagati i podacima o prihodima i rashodima društava i ustanova u njihovom vlasništvu/suvlasništvu (npr. komunalna poduzeća), no podatke o tim društvima i ustanovama javnost ne može pronaći na jednom mjestu.

Treće, velike razlike između prihoda i rashoda u jednoj godini ne moraju biti pokazatelj lošeg planiranja ili ostvarivanja lokalnih proračuna, već mogu biti posljedica velikih prodaja kapitalne imovine (npr. zemljišta ili zgrada) ili velikih ulaganja (npr. u lokalnu infrastrukturu). Za svaku se lokalnu jedinicu dio tih detalja može pronaći na web stranicama Ministarstva financija, ali bi za utvrđivanje potpune slike financijskog stanja lokalne jedinice bilo neophodno da Ministarstvo financija - osim podataka o ostvarenju prihoda i rashoda - na godišnjoj razini objavljuje i podatke iz bilanci svih lokalnih jedinica (podatke o njihovoj imovini, obvezama i kapitalu). ${ }^{8}$

Premda cilj ovog članka nije analizirati fiskalno stanje lokalnih jedinica 20I4., već zainteresiranim čitateljima ponuditi sintezu podataka iz baze Ministarstva financija, ipak valja izdvojiti neke, već na prvi pogled uočene zanimljivosti:

- od prvih dvadeset općina s najvišim prihodom po stanovniku, od I9.313 (Vir) do 8.239 kuna (Rogoznica), sve se, osim jedne - Plitvičkih Jezera - nalaze uz more; od najsiromašnijih dvadesetak općina, s prihodom po stanovniku nižim od I.ooo kuna, ni jedna se ne nalazi uz more;

- od prvih dvadeset gradova s najvišim prihodom po stanovniku, od II.659 kuna (Novalja) do 6.9I4 kuna (Crikvenica), svi se, osim četiri - Vrlike, Lipika, Pazina i Zagreba - nalaze uz more; od najsiromašnijih gradova, s prihodom po stanovniku nižim od 2.ooo kuna, ni jedan se ne nalazi uz more;

- razlike u ukupnim prihodima općina su vrlo velike - od preko 60 mil. kuna u Konavlima, Župi Dubrovačkoj i Matuljima, do 700.000 kuna u Zažablju, a ispod 2 mil. kuna ukupnih prihoda ima čak 20 općina;

- $\quad$ izuzme li se Grad Zagreb s ukupnim prihodima od 6,7 mlrd. kuna, gradovi Split i Rijeka sa 729 i 673 mil. kuna imaju sto puta veće prihode od gradova s najnižim ukupnim prihodima - Hrvatske Kostajnice, Komiže i Klanjca (svi po 7 mil. kuna);

- $\quad$ postoje, dakle, gorespomenuti gradovi sa 7 mil. kuna ukupnih prihoda, ali i spomenute općine s preko 60 mil. kuna ukupnih prihoda!

- 52 općine imaju više od 5.000 stanovnika, od čega ih je 6 s više od Io.ooo stanovnika, dok 60 gradova ima manje od Io.ooo stanovnika, od čega ih je I8 s manje od 5.00o stanovnika;

- u gotovo svim županijama, osim u Sisačko-moslavačkoj, prihodi su blago viši ili neznatno niži od rashoda;

- neke se općine i gradovi ističu po tome što su im ukupni rashodi znatno viši od prihoda, primjerice, u općinama Svetom Petru u Šumi za čak III\%, u Oprtlju za IO3\% i Koprivničkom Ivancu za $97 \%$, te u gradovima Belišću za $39 \%$ i Skradinu za 37\%;

- po znatno višim ukupnim prihodima od rashoda ističu se općine: Viljevo za IIo\%, Tisno za 98\% i Stankovci za $73 \%$, te gradovi Senj za 50\% i Zlatar za $47 \%$.

\footnotetext{
7 Više o zaduživanju trgovačkih društava u vlasništvu/suvlasništvu lokalnih jedinica vidjeti u Bajo i Primorac (20I4).

${ }^{8}$ Moguće je da je dio tih informacija već dostupan ili će uskoro biti dostupan na web stranicama lokalnih jedinica jer su od ove godine prema članku I2. Zakona o proračunu sve lokalne jedinice, proračunski i izvanproračunski korisnici dužni objavljivati godišnje financijske izvještaje na svojim web stranicama najkasnije u roku od osam dana od dana njihove predaje Fini.
} 
Za pretpostaviti je da će ova sinteza (ali i svojevrsna analiza) bogate baze podataka Ministarstva financija ponukati čitatelje da sami posjete tu bazu i podrobnije se informiraju o proračunima svojih lokalnih jedinica te se uključe u analiziranje i odlučivanje o trošenju novca iz lokalnih proračuna. Valja se, također, nadati i da će poslužiti kao podloga za analizu koja bi morala prethoditi eventualnim odlukama o teritorijalnoj i fiskalnoj reorganizaciji države.

Tabela I.

Ostvarenje proračuna općina u 2014.

Po stanovniku, u kunama

Ukupno, u mil. kuna

\begin{tabular}{|c|c|c|c|c|c|c|c|c|c|}
\hline & & Prihodi & Rashodi & $\begin{array}{c}\text { Suficit } \\
\text { ili } \\
\text { deficit }\end{array}$ & $\begin{array}{c}\text { Broj } \\
\text { stanov- } \\
\text { nika }\end{array}$ & Prihodi & Rashodi & $\begin{array}{c}\text { Suficit } \\
\text { ili } \\
\text { deficit }\end{array}$ & $\begin{array}{c}\text { Razina } \\
\text { trans- } \\
\text { parent- } \\
\text { nosti }\end{array}$ \\
\hline 1. & Vir & 19.313 & 13.654 & 5.659 & 3.000 & 57,9 & 41,0 & 17,0 & 3 \\
\hline 2. & Funtana & 12.871 & 19.606 & -6.735 & 907 & 11,7 & 17,8 & $-6,1$ & 3 \\
\hline 3. & Šolta & 12.856 & 12.676 & 181 & 1.700 & 21,9 & 21,5 & 0,3 & 1 \\
\hline 4. & Baška & 12.735 & 10.785 & 1.950 & 1.674 & 21,3 & 18,1 & 3,3 & 2 \\
\hline 5. & Sutivan & 12.042 & 11.133 & 909 & 822 & 9,9 & 9,2 & 0,7 & 0 \\
\hline 6. & Bol & 11.772 & 10.308 & 1.464 & 1.630 & 19,2 & 16,8 & 2,4 & 0 \\
\hline 7. & Kolan & 10.928 & 11.253 & -326 & 791 & 8,6 & 8,9 & $-0,3$ & 0 \\
\hline 8. & Kostrena & 10.599 & 10.295 & 305 & 4.180 & 44,3 & 43,0 & 1,3 & 0 \\
\hline 9. & Omišalj & 10.581 & 10.059 & 522 & 2.983 & 31,6 & 30,0 & 1,6 & 1 \\
\hline 10. & Tisno & 10.578 & 5.321 & 5.257 & 3.094 & 32,7 & 16,5 & 16,3 & 0 \\
\hline 11. & $\begin{array}{l}\text { Malinska - } \\
\text { Dubašnica }\end{array}$ & 10.535 & 11.456 & -920 & 3.134 & 33,0 & 35,9 & $-2,9$ & 3 \\
\hline 12. & Tar-Vabriga & 10.474 & 11.615 & -1.142 & 1.990 & 20,8 & 23,1 & $-2,3$ & 0 \\
\hline 13. & Bale & 9.616 & 7.947 & 1.669 & 1.127 & 10,8 & 9,0 & 1,9 & 3 \\
\hline 14. & Karlobag & 9.372 & 9.158 & 213 & 917 & 8,6 & 8,4 & 0,2 & 0 \\
\hline 15. & Punat & 9.108 & 7.456 & 1.651 & 1.973 & 18,0 & 14,7 & 3,3 & 3 \\
\hline 16. & Vrsar & 9.005 & 8.554 & 450 & 2.162 & 19,5 & 18,5 & 1,0 & 1 \\
\hline 17. & Medulin & 8.892 & 7.556 & 1.336 & 6.481 & 57,6 & 49,0 & 8,7 & 3 \\
\hline 18. & Plitvička Jezera & 8.889 & 6.349 & 2.540 & 4.373 & 38,9 & 27,8 & 11,1 & 2 \\
\hline 19. & Fažana & 8.550 & 8.316 & 234 & 3.635 & 31,1 & 30,2 & 0,9 & 4 \\
\hline 20. & Rogoznica & 8.239 & 7.545 & 694 & 2.345 & 19,3 & 17,7 & 1,6 & 1 \\
\hline 21. & Grožnjan & 8.147 & 10.592 & -2.445 & 736 & 6,0 & 7,8 & $-1,8$ & 2 \\
\hline 22. & Fužine & 8.101 & 7.178 & 923 & 1.592 & 12,9 & 11,4 & 1,5 & 0 \\
\hline 23. & Primošten & 8.096 & 7.037 & 1.059 & 2.828 & 22,9 & 19,9 & 3,0 & 2 \\
\hline 24. & Civljane & 7.952 & 7.709 & 243 & 239 & 1,9 & 1,8 & 0,1 & 3 \\
\hline 25. & Dugopolje & 7.691 & 6.751 & 940 & 3.469 & 26,7 & 23,4 & 3,3 & 0 \\
\hline 26. & Postira & 7.623 & 6.909 & 714 & 1.559 & 11,9 & 10,8 & 1,1 & 1 \\
\hline 27. & Mljet & 7.599 & 6.889 & 710 & 1.088 & 8,3 & 7,5 & 0,8 & 1 \\
\hline 28. & Župa Dubrovačka & 7.531 & 6.607 & 923 & 8.331 & 62,7 & 55,0 & 7,7 & 0 \\
\hline 29. & Zadvarje & 7.426 & 8.217 & -791 & 289 & 2,1 & 2,4 & $-0,2$ & 0 \\
\hline 30. & Starigrad & 7.375 & 8.084 & -710 & 1.876 & 13,8 & 15,2 & $-1,3$ & 3 \\
\hline 31. & Konavle & 7.348 & 8.278 & -930 & 8.577 & 63,0 & 71,0 & $-8,0$ & 1 \\
\hline 32. & Povljana & 7.278 & 7.062 & 216 & 759 & 5,5 & 5,4 & 0,2 & 0 \\
\hline 33. & Ravna Gora & 7.209 & 7.096 & 114 & 2.430 & 17,5 & 17,2 & 0,3 & 1 \\
\hline 34. & Milna & 7.013 & 7.939 & -926 & 1.034 & 7,3 & 8,2 & $-1,0$ & 1 \\
\hline 35. & Pučišća & 7.006 & 6.982 & 24 & 2.171 & 15,2 & 15,2 & 0,1 & 1 \\
\hline 36. & Janjina & 6.818 & 6.847 & -29 & 551 & 3,8 & 3,8 & 0,0 & 1 \\
\hline 37. & Lopar & 6.685 & 6.384 & 302 & 1.263 & 8,4 & 8,1 & 0,4 & 1 \\
\hline 38. & $\begin{array}{l}\text { Dubrovačko } \\
\text { Primorje }\end{array}$ & 6.655 & 8.789 & -2.134 & 2.170 & 14,4 & 19,1 & $-4,6$ & 0 \\
\hline 39. & Baška Voda & 6.546 & 5.662 & 884 & 2.775 & 18,2 & 15,7 & 2,5 & 1 \\
\hline 40. & Kršan & 6.542 & 5.987 & 555 & 2.951 & 19,3 & 17,7 & 1,6 & 1 \\
\hline 41. & Brtonigla & 6.528 & 5.429 & 1.099 & 1.626 & 10,6 & 8,8 & 1,8 & 3 \\
\hline 42. & Mošćenička Draga & 6.382 & 6.810 & -428 & 1.535 & 9,8 & 10,5 & $-0,7$ & 4 \\
\hline 43. & Vrbnik & 6.327 & 5.082 & 1.246 & 1.260 & 8,0 & 6,4 & 1,6 & 4 \\
\hline 44. & Pićan & 6.292 & 5.371 & 921 & 1.827 & 11,5 & 9,8 & 1,7 & 1 \\
\hline 45. & Dobrinj & 6.246 & 5.831 & 415 & 2.078 & 13,0 & 12,1 & 0,9 & 3 \\
\hline
\end{tabular}

NEWSLETTER 98 | KATARINA OTT i MIHAELA BRONIĆ | Ostvarenje proračuna općina, gradova i... | Institut za javne financije 3 
Po stanovniku, u kunama

Ukupno, u mil. kuna

\begin{tabular}{|c|c|c|c|c|c|c|c|c|c|}
\hline & & Prihodi & Rashodi & $\begin{array}{c}\text { Suficit } \\
\text { ili } \\
\text { deficit }\end{array}$ & $\begin{array}{c}\text { Broj } \\
\text { stanov- } \\
\text { nika }\end{array}$ & Prihodi & Rashodi & $\begin{array}{c}\text { Suficit } \\
\text { ili } \\
\text { deficit }\end{array}$ & $\begin{array}{c}\text { Razina } \\
\text { trans- } \\
\text { parent- } \\
\text { nosti }\end{array}$ \\
\hline 46. & Nerežišća & 6.175 & 6.985 & -811 & 862 & 5,3 & 6,0 & $-0,7$ & 0 \\
\hline 47. & Lastovo & 6.140 & 5.694 & 446 & 792 & 4,9 & 4,5 & 0,4 & 3 \\
\hline 48. & Saborsko & 5.950 & 6.265 & -316 & 632 & 3,8 & 4,0 & $-0,2$ & 2 \\
\hline 49. & Tribunj & 5.913 & 5.861 & 52 & 1.536 & 9,1 & 9,0 & 0,1 & 3 \\
\hline 50. & Motovun & 5.835 & 5.708 & 127 & 1.004 & 5,9 & 5,7 & 0,1 & 0 \\
\hline 51. & Tkon & 5.828 & 4.919 & 909 & 763 & 4,4 & 3,8 & 0,7 & 1 \\
\hline 52. & Brela & 5.752 & 6.215 & -462 & 1.703 & 9,8 & 10,6 & $-0,8$ & 2 \\
\hline 53. & Kalinovac & 5.685 & 7.618 & -1.933 & 1.597 & 9,1 & 12,2 & $-3,1$ & 2 \\
\hline 54. & Sveti Lovreč & 5.680 & 5.768 & -88 & 1.015 & 5,8 & 5,9 & $-0,1$ & 1 \\
\hline 55. & Kijevo & 5.644 & 4.899 & 745 & 417 & 2,4 & 2,0 & 0,3 & 0 \\
\hline 56. & Jasenice & 5.618 & 6.897 & -1.278 & 1.398 & 7,9 & 9,6 & $-1,8$ & 2 \\
\hline 57. & Lovinac & 5.617 & 6.605 & -987 & 1.007 & 5,7 & 6,7 & $-1,0$ & 3 \\
\hline 58. & Matulji & 5.391 & 4.607 & 784 & 11.246 & 60,6 & 51,8 & 8,8 & 4 \\
\hline 59. & Vižinada & 5.367 & 3.346 & 2.021 & 1.158 & 6,2 & 3,9 & 2,3 & 1 \\
\hline 60. & Murter & 5.363 & 5.324 & 38 & 2.044 & 11,0 & 10,9 & 0,1 & 3 \\
\hline 61. & Podgora & 5.306 & 6.316 & -1.010 & 2.518 & 13,4 & 15,9 & $-2,5$ & 0 \\
\hline 62. & Lovran & 5.298 & 5.396 & -98 & 4.101 & 21,7 & 22,1 & $-0,4$ & 1 \\
\hline 63. & Molve & 5.265 & 5.758 & -493 & 2.189 & 11,5 & 12,6 & $-1,1$ & 3 \\
\hline 64. & Lećevica & 5.263 & 7.908 & -2.644 & 583 & 3,1 & 4,6 & $-1,5$ & 2 \\
\hline 65. & Kanfanar & 5.082 & 5.305 & -223 & 1.543 & 7,8 & 8,2 & $-0,3$ & 3 \\
\hline 66. & Tučepi & 5.065 & 5.107 & -42 & 1.931 & 9,8 & 9,9 & $-0,1$ & 0 \\
\hline 67. & Kukljica & 4.981 & 4.907 & 74 & 714 & 3,6 & 3,5 & 0,1 & 0 \\
\hline 68. & Ston & 4.883 & 5.176 & -293 & 2.407 & 11,8 & 12,5 & $-0,7$ & 3 \\
\hline 69. & Nova Bukovica & 4.876 & 5.155 & -279 & 1.771 & 8,6 & 9,1 & $-0,5$ & 0 \\
\hline 70. & Magadenovac & 4.844 & 4.763 & 81 & 1.936 & 9,4 & 9,2 & 0,2 & 1 \\
\hline 71. & Rakovica & 4.804 & 4.170 & 634 & 2.387 & 11,5 & 10,0 & 1,5 & 4 \\
\hline 72. & Blato & 4.794 & 4.041 & 753 & 3.593 & 17,2 & 14,5 & 2,7 & 3 \\
\hline 73. & Klana & 4.785 & 3.595 & 1.190 & 1.975 & 9,4 & 7,1 & 2,3 & 0 \\
\hline 74. & Lokve & 4.765 & 4.411 & 353 & 1.049 & 5,0 & 4,6 & 0,4 & 1 \\
\hline 75. & Gračišće & 4.704 & 2.878 & 1.825 & 1.419 & 6,7 & 4,1 & 2,6 & 3 \\
\hline 76. & Sali & 4.697 & 3.622 & 1.075 & 1.698 & 8,0 & 6,2 & 1,8 & 2 \\
\hline 77. & Okrug & 4.683 & 5.528 & -845 & 3.349 & 15,7 & 18,5 & $-2,8$ & 2 \\
\hline 78. & Čavle & 4.683 & 4.459 & 224 & 7.220 & 33,8 & 32,2 & 1,6 & 2 \\
\hline 79. & Tinjan & 4.673 & 2.774 & 1.899 & 1.684 & 7,9 & 4,7 & 3,2 & 0 \\
\hline 80. & Jelsa & 4.637 & 4.603 & 34 & 3.582 & 16,6 & 16,5 & 0,1 & 0 \\
\hline 81. & Stubičke Toplice & 4.602 & 4.644 & -42 & 2.805 & 12,9 & 13,0 & $-0,1$ & 3 \\
\hline 82. & Vinodolska općina & 4.591 & 4.591 & -1 & 3.577 & 16,4 & 16,4 & 0,0 & 1 \\
\hline 83. & Stupnik & 4.568 & 3.984 & 584 & 3.735 & 17,1 & 14,9 & 2,2 & 3 \\
\hline 84. & Trpanj & 4.542 & 4.377 & 165 & 721 & 3,3 & 3,2 & 0,1 & 3 \\
\hline 85. & Raša & 4.540 & 4.415 & 125 & 3.183 & 14,5 & 14,1 & 0,4 & 1 \\
\hline 86. & Pirovac & 4.474 & 3.905 & 569 & 1.930 & 8,6 & 7,5 & 1,1 & 4 \\
\hline 87. & Pisarovina & 4.454 & 4.127 & 327 & 3.689 & 16,4 & 15,2 & 1,2 & 0 \\
\hline 88. & Mrkopalj & 4.425 & 4.362 & 63 & 1.214 & 5,4 & 5,3 & 0,1 & 2 \\
\hline 89. & Perušić & 4.415 & 3.239 & 1.175 & 2.638 & 11,6 & 8,5 & 3,1 & 1 \\
\hline 90. & Pakoštane & 4.349 & 4.676 & -328 & 4.123 & 17,9 & 19,3 & $-1,4$ & 0 \\
\hline 91. & Primorski Dolac & 4.270 & 6.315 & -2.046 & 770 & 3,3 & 4,9 & $-1,6$ & 2 \\
\hline 92. & Oprtalj & 4.216 & 8.569 & -4.353 & 850 & 3,6 & 7,3 & $-3,7$ & 1 \\
\hline 93. & Stankovci & 4.205 & 2.419 & 1.785 & 2.003 & 8,4 & 4,8 & 3,6 & 0 \\
\hline 94. & Lupoglav & 4.192 & 6.528 & -2.336 & 924 & 3,9 & 6,0 & $-2,2$ & 0 \\
\hline 95. & Preko & 4.177 & 4.161 & 16 & 3.805 & 15,9 & 15,8 & 0,1 & 0 \\
\hline 96. & Orebić & 4.155 & 3.933 & 221 & 4.122 & 17,1 & 16,2 & 0,9 & 0 \\
\hline 97. & Zemunik Donji & 4.064 & 5.263 & -1.198 & 2.060 & 8,4 & 10,8 & $-2,5$ & 0 \\
\hline 98. & Barilović & 4.059 & 2.493 & 1.566 & 2.990 & 12,1 & 7,5 & 4,7 & 1 \\
\hline 99. & Drenovci & 4.040 & 3.267 & 773 & 5.174 & 20,9 & 16,9 & 4,0 & 3 \\
\hline 100. & Pašman & 4.038 & 5.139 & -1.101 & 2.082 & 8,4 & 10,7 & $-2,3$ & 2 \\
\hline 101. & Crnac & 4.024 & 3.169 & 855 & 1.456 & 5,9 & 4,6 & 1,2 & 4 \\
\hline
\end{tabular}

4 NEWSLETTER 98 | KATARINA OTT i MIHAELA BRONIĆ | Ostvarenje proračuna općina, gradova i... | Institut za javne financije 
Po stanovniku, u kunama

Ukupno, u mil. kuna

\begin{tabular}{|c|c|c|c|c|c|c|c|c|c|}
\hline & & Prihodi & Rashodi & $\begin{array}{c}\text { Suficit } \\
\text { ili } \\
\text { deficit }\end{array}$ & $\begin{array}{c}\text { Broj } \\
\text { stanov- } \\
\text { nika }\end{array}$ & Prihodi & Rashodi & $\begin{array}{c}\text { Suficit } \\
\text { ili } \\
\text { deficit }\end{array}$ & $\begin{array}{c}\text { Razina } \\
\text { trans- } \\
\text { parent- } \\
\text { nosti }\end{array}$ \\
\hline 102. & Privlaka (Zadar) & 3.900 & 3.252 & 648 & 2.253 & 8,8 & 7,3 & 1,5 & 3 \\
\hline 103. & Podravske Sesvete & 3.869 & 4.319 & -449 & 1.630 & 6,3 & 7,0 & $-0,7$ & 0 \\
\hline 104. & Cerovlje & 3.869 & 3.797 & 73 & 1.677 & 6,5 & 6,4 & 0,1 & 1 \\
\hline 105. & Vrsi & 3.860 & 3.720 & 140 & 2.053 & 7,9 & 7,6 & 0,3 & 0 \\
\hline 106. & Viškovo & 3.846 & 4.816 & -970 & 14.445 & 55,6 & 69,6 & $-14,0$ & 5 \\
\hline 107. & Sveti Filip i Jakov & 3.826 & 3.400 & 426 & 4.606 & 17,6 & 15,7 & 2,0 & 2 \\
\hline 108. & Sućuraj & 3.824 & 6.372 & -2.548 & 463 & 1,8 & 3,0 & $-1,2$ & 0 \\
\hline 109. & Kali & 3.780 & 3.661 & 119 & 1.638 & 6,2 & 6,0 & 0,2 & 1 \\
\hline 110. & Koprivnički Bregi & 3.758 & 3.752 & 6 & 2.381 & 8,9 & 8,9 & 0,0 & 3 \\
\hline 111. & Prgomet & 3.745 & 3.346 & 399 & 673 & 2,5 & 2,3 & 0,3 & 0 \\
\hline 112. & Svetvinčenat & 3.737 & 4.335 & -598 & 2.202 & 8,2 & 9,5 & $-1,3$ & 0 \\
\hline 113. & Jalžabet & 3.670 & 3.126 & 544 & 3.615 & 13,3 & 11,3 & 2,0 & 1 \\
\hline 114. & Novigrad & 3.669 & 4.479 & -810 & 2.375 & 8,7 & 10,6 & $-1,9$ & 1 \\
\hline 115. & Kneževi Vinogradi & 3.666 & 4.214 & -548 & 4.614 & 16,9 & 19,4 & $-2,5$ & 1 \\
\hline 116. & $\begin{array}{l}\text { Sveta Nedelja } \\
\text { (Istra) }\end{array}$ & 3.645 & 4.148 & -503 & 2.987 & 10,9 & 12,4 & $-1,5$ & 4 \\
\hline 117. & Legrad & 3.642 & 4.418 & -775 & 2.241 & 8,2 & 9,9 & $-1,7$ & 1 \\
\hline 118. & Skrad & 3.639 & 3.777 & -138 & 1.062 & 3,9 & 4,0 & $-0,1$ & 3 \\
\hline 119. & Marčana & 3.637 & 3.589 & 48 & 4.253 & 15,5 & 15,3 & 0,2 & 3 \\
\hline 120. & Ribnik & 3.608 & 3.435 & 173 & 475 & 1,7 & 1,6 & 0,1 & 4 \\
\hline 121. & Ljubešćica & 3.587 & 3.761 & -174 & 1.858 & 6,7 & 7,0 & $-0,3$ & 2 \\
\hline 122. & Jasenovac & 3.556 & 2.485 & 1.071 & 1.997 & 7,1 & 5,0 & 2,1 & 1 \\
\hline 123. & Lanišće & 3.555 & 3.802 & -247 & 329 & 1,2 & 1,3 & $-0,1$ & 2 \\
\hline 124. & Polača & 3.522 & 3.263 & 259 & 1.468 & 5,2 & 4,8 & 0,4 & 1 \\
\hline 125. & Klis & 3.513 & 3.786 & -272 & 4.801 & 16,9 & 18,2 & $-1,3$ & 2 \\
\hline 126. & Marina & 3.494 & 3.644 & -150 & 4.595 & 16,1 & 16,7 & $-0,7$ & 0 \\
\hline 127. & Poličnik & 3.494 & 3.465 & 29 & 4.469 & 15,6 & 15,5 & 0,1 & 0 \\
\hline 128. & Jesenje & 3.435 & 3.599 & -164 & 1.560 & 5,4 & 5,6 & $-0,3$ & 2 \\
\hline 129. & Kaštelir - Labinci & 3.396 & 3.975 & -579 & 1.463 & 5,0 & 5,8 & $-0,8$ & 1 \\
\hline 130. & Radoboj & 3.351 & 3.122 & 229 & 3.387 & 11,3 & 10,6 & 0,8 & 1 \\
\hline 131. & Hrvace & 3.336 & 3.146 & 190 & 3.617 & 12,1 & 11,4 & 0,7 & 0 \\
\hline 132. & Marija Gorica & 3.326 & 2.562 & 764 & 2.233 & 7,4 & 5,7 & 1,7 & 0 \\
\hline 133. & Bistra & 3.320 & 3.078 & 243 & 6.632 & 22,0 & 20,4 & 1,6 & 3 \\
\hline 134. & Lovas & 3.306 & 3.356 & -50 & 1.214 & 4,0 & 4,1 & $-0,1$ & 3 \\
\hline 135. & Luka & 3.293 & 3.609 & -316 & 1.351 & 4,4 & 4,9 & $-0,4$ & 2 \\
\hline 136. & Udbina & 3.284 & 3.256 & 29 & 1.874 & 6,2 & 6,1 & 0,1 & 3 \\
\hline 137. & Gola & 3.281 & 4.995 & -1.714 & 2.431 & 8,0 & 12,1 & $-4,2$ & 0 \\
\hline 138. & Zagvozd & 3.260 & 3.627 & -367 & 1.188 & 3,9 & 4,3 & $-0,4$ & 0 \\
\hline 139. & Ervenik & 3.216 & 2.293 & 923 & 1.105 & 3,6 & 2,5 & 1,0 & 3 \\
\hline 140. & Peteranec & 3.196 & 2.788 & 408 & 2.704 & 8,6 & 7,5 & 1,1 & 0 \\
\hline 141. & Klakar & 3.192 & 2.006 & 1.186 & 2.319 & 7,4 & 4,7 & 2,8 & 4 \\
\hline 142. & Viljevo & 3.190 & 1.516 & 1.675 & 2.065 & 6,6 & 3,1 & 3,5 & 3 \\
\hline 143. & Gradac & 3.188 & 3.153 & 34 & 3.261 & 10,4 & 10,3 & 0,1 & 3 \\
\hline 144. & Majur & 3.163 & 2.447 & 716 & 1.185 & 3,7 & 2,9 & 0,8 & 0 \\
\hline 145. & Sirač & 3.099 & 2.986 & 112 & 2.218 & 6,9 & 6,6 & 0,2 & 1 \\
\hline 146. & Brod Moravice & 3.090 & 3.087 & 2 & 866 & 2,7 & 2,7 & 0,0 & 3 \\
\hline 147. & Smokvica & 3.079 & 2.709 & 370 & 916 & 2,8 & 2,5 & 0,3 & 1 \\
\hline 148. & Nijemci & 3.073 & 3.635 & -562 & 4.705 & 14,5 & 17,1 & $-2,6$ & 3 \\
\hline 149. & Jelenje & 3.071 & 2.952 & 118 & 5.344 & 16,4 & 15,8 & 0,6 & 3 \\
\hline 150. & Bibinje & 3.070 & 3.094 & -25 & 3.985 & 12,2 & 12,3 & $-0,1$ & 0 \\
\hline 151. & Lišane Ostrovičke & 3.063 & 3.721 & -658 & 698 & 2,1 & 2,6 & $-0,5$ & 0 \\
\hline 152. & Podstrana & 3.048 & 3.361 & -313 & 9.129 & 27,8 & 30,7 & $-2,9$ & 0 \\
\hline 153. & Ližnjan & 3.024 & 4.708 & -1.684 & 3.965 & 12,0 & 18,7 & $-6,7$ & 1 \\
\hline 154. & Višnjan & 3.013 & 3.433 & -420 & 2.274 & 6,9 & 7,8 & $-1,0$ & 2 \\
\hline 155. & Virje & 3.012 & 2.907 & 105 & 4.587 & 13,8 & 13,3 & 0,5 & 1 \\
\hline 156. & Antunovac & 3.001 & 2.467 & 534 & 3.703 & 11,1 & 9,1 & 2,0 & 3 \\
\hline
\end{tabular}

NEWSLETTER 98 | KATARINA OTT i MIHAELA BRONIĆ | Ostvarenje proračuna općina, gradova i... | Institut za javne financije 5 
Po stanovniku, u kunama

Ukupno, u mil. kuna

\begin{tabular}{|c|c|c|c|c|c|c|c|c|c|}
\hline & & & \\
\hline & & Prihodi & Rashodi & $\begin{array}{c}\text { Suficit } \\
\text { ili } \\
\text { deficit }\end{array}$ & $\begin{array}{c}\text { Broj } \\
\text { stanov- } \\
\text { nika }\end{array}$ & Prihodi & Rashodi & $\begin{array}{c}\text { Suficit } \\
\text { ili } \\
\text { deficit }\end{array}$ & $\begin{array}{c}\text { Razina } \\
\text { trans- } \\
\text { parent- } \\
\text { nosti }\end{array}$ \\
\hline 157. & Selca & 2.943 & 3.231 & -288 & 1.804 & 5,3 & 5,8 & $-0,5$ & 3 \\
\hline 158. & Gunja & 2.940 & 2.205 & 735 & 3.732 & 11,0 & 8,2 & 2,7 & 0 \\
\hline 159. & Posedarje & 2.908 & 2.812 & 96 & 3.607 & 10,5 & 10,1 & 0,3 & 0 \\
\hline 160. & Bilje & 2.906 & 3.635 & -729 & 5.642 & 16,4 & 20,5 & $-4,1$ & 1 \\
\hline 161. & Bosiljevo & 2.904 & 2.330 & 575 & 1.284 & 3,7 & 3,0 & 0,7 & 3 \\
\hline 162. & Čađavica & 2.876 & 2.614 & 263 & 2.009 & 5,8 & 5,3 & 0,5 & 0 \\
\hline 163. & Pušća & 2.866 & 2.517 & 349 & 2.700 & 7,7 & 6,8 & 0,9 & 0 \\
\hline 164. & Velika & 2.857 & 2.474 & 383 & 5.607 & 16,0 & 13,9 & 2,1 & 3 \\
\hline 165. & Cestica & 2.856 & 2.273 & 583 & 5.806 & 16,6 & 13,2 & 3,4 & 1 \\
\hline 166. & Dicmo & 2.851 & 3.314 & -463 & 2.802 & 8,0 & 9,3 & $-1,3$ & 0 \\
\hline 167. & Sukošan & 2.828 & 2.663 & 165 & 4.583 & 13,0 & 12,2 & 0,8 & 3 \\
\hline 168. & Lipovljani & 2.820 & 2.883 & -63 & 3.455 & 9,7 & 10,0 & $-0,2$ & 3 \\
\hline 169. & Lumbarda & 2.820 & 2.382 & 438 & 1.213 & 3,4 & 2,9 & 0,5 & 1 \\
\hline 170. & Lokvičići & 2.817 & 2.772 & 44 & 807 & 2,3 & 2,2 & 0,0 & 0 \\
\hline 171. & Seget & 2.812 & 2.293 & 518 & 4.854 & 13,6 & 11,1 & 2,5 & 2 \\
\hline 172. & Zagorska Sela & 2.798 & 3.110 & -312 & 996 & 2,8 & 3,1 & $-0,3$ & 0 \\
\hline 173. & Vela Luka & 2.768 & 2.231 & 537 & 4.137 & 11,4 & 9,2 & 2,2 & 3 \\
\hline 174. & Drnje & 2.759 & 2.702 & 57 & 1.863 & 5,1 & 5,0 & 0,1 & 2 \\
\hline 175. & Vrbanja & 2.753 & 2.926 & -172 & 3.940 & 10,8 & 11,5 & $-0,7$ & 3 \\
\hline 176. & Ražanac & 2.720 & 2.692 & 27 & 2.940 & 8,0 & 7,9 & 0,1 & 0 \\
\hline 177. & Križ & 2.712 & 2.998 & -285 & 6.963 & 18,9 & 20,9 & $-2,0$ & 3 \\
\hline 178. & Vrhovine & 2.683 & 2.982 & -299 & 1.381 & 3,7 & 4,1 & $-0,4$ & 3 \\
\hline 179. & Brinje & 2.675 & 2.917 & -242 & 3.256 & 8,7 & 9,5 & $-0,8$ & 1 \\
\hline 180. & Jagodnjak & 2.653 & 3.816 & -1.163 & 2.023 & 5,4 & 7,7 & $-2,4$ & 0 \\
\hline 181. & Bilice & 2.643 & 2.344 & 299 & 2.307 & 6,1 & 5,4 & 0,7 & 2 \\
\hline 182. & Gračac & 2.631 & 2.660 & -29 & 4.690 & 12,3 & 12,5 & $-0,1$ & 3 \\
\hline 183. & Dugi Rat & 2.609 & 2.123 & 486 & 7.092 & 18,5 & 15,1 & 3,4 & 0 \\
\hline 184. & Žumberak & 2.584 & 2.190 & 394 & 883 & 2,3 & 1,9 & 0,3 & 0 \\
\hline 185. & Dekanovec & 2.578 & 1.981 & 597 & 774 & 2,0 & 1,5 & 0,5 & 0 \\
\hline 186. & Brdovec & 2.567 & 2.583 & -16 & 11.134 & 28,6 & 28,8 & $-0,2$ & 0 \\
\hline 187. & Petlovac & 2.547 & 3.159 & -612 & 2.405 & 6,1 & 7,6 & $-1,5$ & 3 \\
\hline 188. & Promina & 2.535 & 2.299 & 236 & 1.136 & 2,9 & 2,6 & 0,3 & 1 \\
\hline 189. & Lasinja & 2.521 & 2.434 & 88 & 1.624 & 4,1 & 4,0 & 0,1 & 3 \\
\hline 190. & Stara Gradiška & 2.510 & 2.407 & 104 & 1.363 & 3,4 & 3,3 & 0,1 & 0 \\
\hline 191. & Hum na Sutli & 2.502 & 2.503 & -1 & 5.060 & 12,7 & 12,7 & 0,0 & 1 \\
\hline 192. & Đurmanec & 2.487 & 2.395 & 92 & 4.235 & 10,5 & 10,1 & 0,4 & 2 \\
\hline 193. & Gradište & 2.481 & 1.473 & 1.008 & 2.773 & 6,9 & 4,1 & 2,8 & 0 \\
\hline 194. & Tovarnik & 2.473 & 2.645 & -172 & 2.775 & 6,9 & 7,3 & $-0,5$ & 4 \\
\hline 195. & Semeljci & 2.472 & 2.499 & -28 & 4.362 & 10,8 & 10,9 & $-0,1$ & 2 \\
\hline 196. & Tounj & 2.469 & 1.659 & 810 & 1.150 & 2,8 & 1,9 & 0,9 & 4 \\
\hline 197. & Barban & 2.441 & 3.506 & -1.065 & 2.721 & 6,6 & 9,5 & $-2,9$ & 0 \\
\hline 198. & Josipdol & 2.425 & 2.316 & 109 & 3.773 & 9,2 & 8,7 & 0,4 & 2 \\
\hline 199. & Tordinci & 2.387 & 2.045 & 342 & 2.032 & 4,8 & 4,2 & 0,7 & 0 \\
\hline 200. & Gornji Kneginec & 2.369 & 1.670 & 699 & 5.349 & 12,7 & 8,9 & 3,7 & 1 \\
\hline 201. & Gornja Stubica & 2.367 & 2.531 & -164 & 5.284 & 12,5 & 13,4 & $-0,9$ & 0 \\
\hline 202. & Kalnik & 2.361 & 2.260 & 102 & 1.351 & 3,2 & 3,1 & 0,1 & 2 \\
\hline 203. & $\begin{array}{l}\text { Novigrad } \\
\text { Podravski }\end{array}$ & 2.360 & 2.304 & 56 & 2.872 & 6,8 & 6,6 & 0,2 & 2 \\
\hline 204. & Tompojevci & 2.357 & 2.669 & -313 & 1.565 & 3,7 & 4,2 & $-0,5$ & 2 \\
\hline 205. & Kravarsko & 2.341 & 2.115 & 227 & 1.987 & 4,7 & 4,2 & 0,5 & 2 \\
\hline 206. & Vladislavci & 2.337 & 2.368 & -32 & 1.882 & 4,4 & 4,5 & $-0,1$ & 2 \\
\hline 207. & Zdenci & 2.316 & 1.954 & 362 & 1.904 & 4,4 & 3,7 & 0,7 & 1 \\
\hline 208. & Cista Provo & 2.289 & 2.542 & -254 & 2.335 & 5,3 & 5,9 & $-0,6$ & 0 \\
\hline 209. & Otok (Split) & 2.282 & 2.077 & 205 & 5.474 & 12,5 & 11,4 & 1,1 & 0 \\
\hline 210. & Proložac & 2.277 & 2.888 & -611 & 3.802 & 8,7 & 11,0 & $-2,3$ & 0 \\
\hline 211. & Šandrovac & 2.275 & 2.390 & -115 & 1.776 & 4,0 & 4,2 & $-0,2$ & 3 \\
\hline 212. & Žminj & 2.271 & 2.515 & -244 & 3.483 & 7,9 & 8,8 & $-0,8$ & 3 \\
\hline
\end{tabular}

6 NEWSLETTER 98 | KATARINA OTT i MIHAELA BRONIĆ | Ostvarenje proračuna općina, gradova i... | Institut za javne financije 
Po stanovniku, u kunama

Ukupno, u mil. kuna

\begin{tabular}{|c|c|c|c|c|c|c|c|c|c|}
\hline & & Prihodi & Rashodi & $\begin{array}{c}\text { Suficit } \\
\text { ili } \\
\text { deficit }\end{array}$ & $\begin{array}{c}\text { Broj } \\
\text { stanov- } \\
\text { nika }\end{array}$ & Prihodi & Rashodi & $\begin{array}{c}\text { Suficit } \\
\text { ili } \\
\text { deficit }\end{array}$ & $\begin{array}{c}\text { Razina } \\
\text { trans- } \\
\text { parent- } \\
\text { nosti }\end{array}$ \\
\hline 213. & $\begin{array}{l}\text { Podravska } \\
\text { Moslavina }\end{array}$ & 2.271 & 2.267 & 4 & 1.202 & 2,7 & 2,7 & 0,0 & 0 \\
\hline 214. & Unešić & 2.267 & 2.156 & 110 & 1.686 & 3,8 & 3,6 & 0,2 & 0 \\
\hline 215. & Rugvica & 2.264 & 1.870 & 394 & 7.871 & 17,8 & 14,7 & 3,1 & 0 \\
\hline 216. & Čeminac & 2.255 & 2.083 & 172 & 2.909 & 6,6 & 6,1 & 0,5 & 0 \\
\hline 217. & Sveti Petar u Šumi & 2.254 & 4.758 & -2.504 & 1.065 & 2,4 & 5,1 & $-2,7$ & 0 \\
\hline 218. & Veliki Grđevac & 2.251 & 2.108 & 144 & 2.849 & 6,4 & 6,0 & 0,4 & 0 \\
\hline 219. & Muć & 2.245 & 1.866 & 379 & 3.882 & 8,7 & 7,2 & 1,5 & 1 \\
\hline 220. & Konjščina & 2.242 & 2.620 & -378 & 3.790 & 8,5 & 9,9 & $-1,4$ & 3 \\
\hline 221. & Voćin & 2.235 & 3.020 & -785 & 2.382 & 5,3 & 7,2 & $-1,9$ & 0 \\
\hline 222. & Draž & 2.226 & 2.205 & 21 & 2.767 & 6,2 & 6,1 & 0,1 & 0 \\
\hline 223. & Zlatar Bistrica & 2.163 & 2.304 & -141 & 2.600 & 5,6 & 6,0 & $-0,4$ & 1 \\
\hline 224. & Ružić & 2.158 & 1.918 & 240 & 1.591 & 3,4 & 3,1 & 0,4 & 3 \\
\hline 225. & Šestanovac & 2.154 & 2.424 & -270 & 1.958 & 4,2 & 4,7 & $-0,5$ & 1 \\
\hline 226. & Lovreć & 2.147 & 2.146 & 1 & 1.699 & 3,6 & 3,6 & 0,0 & 1 \\
\hline 227. & Pokupsko & 2.138 & 2.259 & -121 & 2.224 & 4,8 & 5,0 & $-0,3$ & 0 \\
\hline 228. & Veliko Trojstvo & 2.137 & 1.949 & 188 & 2.741 & 5,9 & 5,3 & 0,5 & 0 \\
\hline 229. & Suhopolje & 2.130 & 1.989 & 142 & 6.683 & 14,2 & 13,3 & 0,9 & 1 \\
\hline 230. & Erdut & 2.123 & 2.075 & 48 & 7.308 & 15,5 & 15,2 & 0,4 & 2 \\
\hline 231. & $\begin{array}{l}\text { Sveti Juraj } \\
\text { na Bregu }\end{array}$ & 2.119 & 2.253 & -135 & 5.090 & 10,8 & 11,5 & $-0,7$ & 1 \\
\hline 232. & Dubravica & 2.119 & 2.723 & -604 & 1.437 & 3,0 & 3,9 & $-0,9$ & 2 \\
\hline 233. & Topusko & 2.118 & 2.334 & -216 & 2.985 & 6,3 & 7,0 & $-0,6$ & 3 \\
\hline 234. & Brckovljani & 2.105 & 1.932 & 174 & 6.837 & 14,4 & 13,2 & 1,2 & 0 \\
\hline 235. & Privlaka (Vinkovci) & 2.080 & 2.297 & -217 & 2.954 & 6,1 & 6,8 & $-0,6$ & 0 \\
\hline 236. & Kloštar Ivanić & 2.075 & 2.140 & -65 & 6.091 & 12,6 & 13,0 & $-0,4$ & 1 \\
\hline 237. & Novo Virje & 2.058 & 1.783 & 276 & 1.216 & 2,5 & 2,2 & 0,3 & 0 \\
\hline 238. & Orehovica & 2.043 & 1.795 & 247 & 2.685 & 5,5 & 4,8 & 0,7 & 0 \\
\hline 239. & Novi Golubovec & 2.042 & 1.758 & 284 & 996 & 2,0 & 1,8 & 0,3 & 0 \\
\hline 240. & Šenkovec & 2.040 & 2.106 & -66 & 2.879 & 5,9 & 6,1 & $-0,2$ & 0 \\
\hline 241. & Zmijavci & 2.039 & 2.158 & -120 & 2.048 & 4,2 & 4,4 & $-0,2$ & 1 \\
\hline 242. & Karojba & 2.028 & 2.819 & -791 & 1.438 & 2,9 & 4,1 & $-1,1$ & 0 \\
\hline 243. & Severin & 2.025 & 2.084 & -60 & 877 & 1,8 & 1,8 & $-0,1$ & 0 \\
\hline 244. & Generalski Stol & 2.019 & 1.846 & 172 & 2.642 & 5,3 & 4,9 & 0,5 & 3 \\
\hline 245. & Bednja & 2.012 & 1.943 & 68 & 3.992 & 8,0 & 7,8 & 0,3 & 0 \\
\hline 246. & Kraljevec na Sutli & 2.011 & 2.142 & -131 & 1.727 & 3,5 & 3,7 & $-0,2$ & 2 \\
\hline 247. & Marija Bistrica & 2.010 & 2.350 & -340 & 5.976 & 12,0 & 14,0 & $-2,0$ & 0 \\
\hline 248. & Oriovac & 2.007 & 1.671 & 336 & 5.824 & 11,7 & 9,7 & 2,0 & 1 \\
\hline 249. & Vuka & 2.001 & 1.643 & 358 & 1.200 & 2,4 & 2,0 & 0,4 & 3 \\
\hline 250. & Berek & 1.997 & 2.011 & -15 & 1.443 & 2,9 & 2,9 & 0,0 & 1 \\
\hline 251. & Šodolovci & 1.995 & 1.816 & 179 & 1.653 & 3,3 & 3,0 & 0,3 & 1 \\
\hline 252. & Gornja Rijeka & 1.986 & 1.711 & 275 & 1.779 & 3,5 & 3,0 & 0,5 & 2 \\
\hline 253. & Bedenica & 1.968 & 1.669 & 299 & 1.432 & 2,8 & 2,4 & 0,4 & 0 \\
\hline 254. & Davor & 1.959 & 2.343 & -384 & 3.015 & 5,9 & 7,1 & $-1,2$ & 0 \\
\hline 255. & Velika Ludina & 1.952 & 2.784 & -832 & 2.625 & 5,1 & 7,3 & $-2,2$ & 2 \\
\hline 256. & Popovac & 1.944 & 2.273 & -329 & 2.084 & 4,1 & 4,7 & $-0,7$ & 2 \\
\hline 257. & Škabrnja & 1.927 & 1.865 & 62 & 1.776 & 3,4 & 3,3 & 0,1 & 0 \\
\hline 258. & Krapinske Toplice & 1.919 & 1.971 & -52 & 5.367 & 10,3 & 10,6 & $-0,3$ & 3 \\
\hline 259. & Stari Jankovci & 1.913 & 1.884 & 28 & 4.405 & 8,4 & 8,3 & 0,1 & 2 \\
\hline 260. & Lekenik & 1.906 & 1.905 & 1 & 6.032 & 11,5 & 11,5 & 0,0 & 0 \\
\hline 261. & Tuhelj & 1.905 & 1.671 & 233 & 2.104 & 4,0 & 3,5 & 0,5 & 3 \\
\hline 262. & Kamanje & 1.887 & 2.409 & -522 & 891 & 1,7 & 2,1 & $-0,5$ & 3 \\
\hline 263. & Veliko Trgovišće & 1.881 & 1.998 & -117 & 4.945 & 9,3 & 9,9 & $-0,6$ & 1 \\
\hline 264. & Darda & 1.875 & 2.436 & -560 & 6.908 & 13,0 & 16,8 & $-3,9$ & 2 \\
\hline 265. & Lobor & 1.874 & 1.624 & 250 & 3.188 & 6,0 & 5,2 & 0,8 & 2 \\
\hline 266. & Satnica Đakovačka & 1.860 & 1.851 & 9 & 2.123 & 3,9 & 3,9 & 0,0 & 1 \\
\hline
\end{tabular}

NEWSLETTER 98 | KATARINA OTT i MIHAELA BRONIĆ | Ostvarenje proračuna općina, gradova i... $\mid$ Institut za javne financije 7 
Po stanovniku, u kunama

Ukupno, u mil. kuna

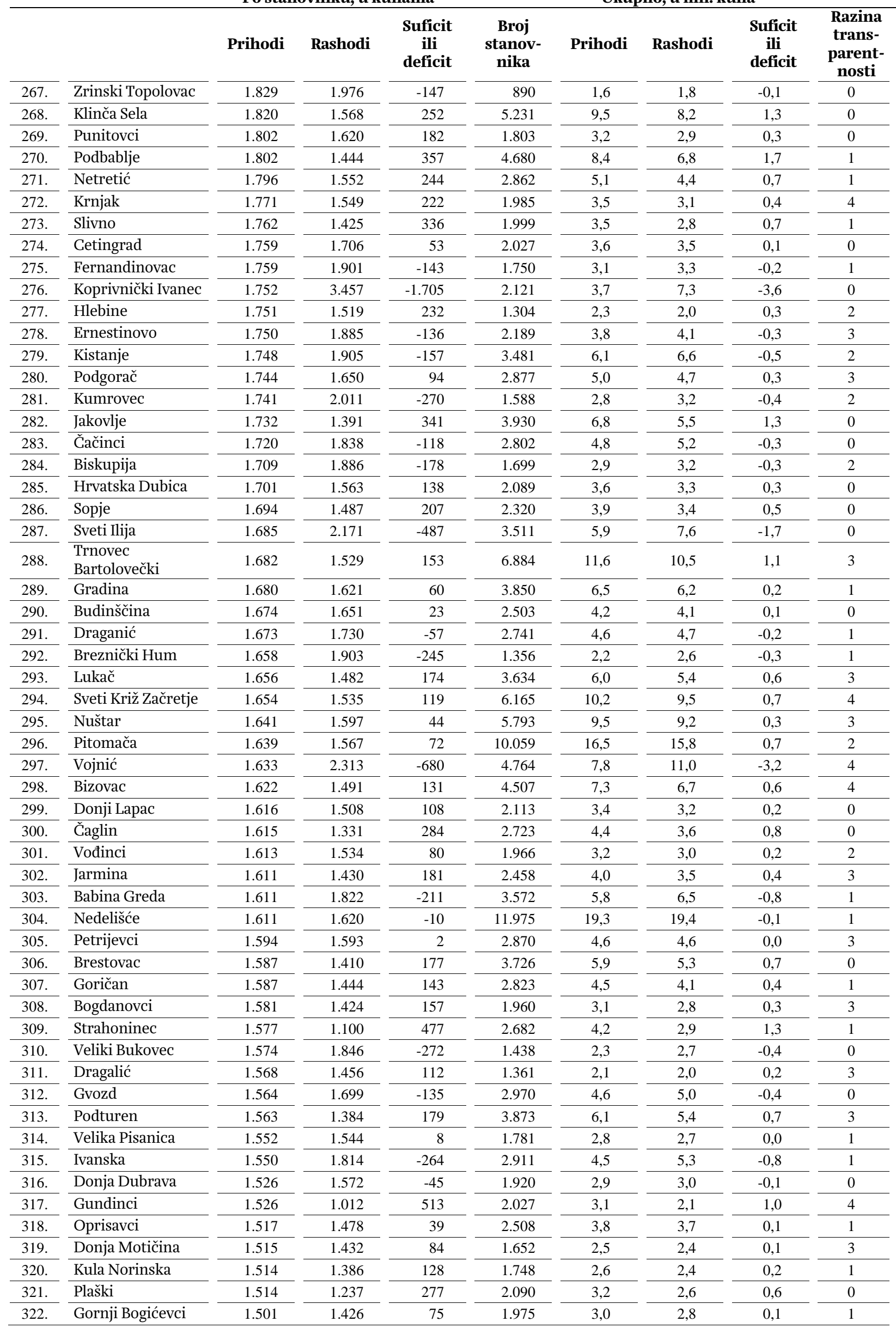


Po stanovniku, u kunama

Ukupno, u mil. kuna

\begin{tabular}{|c|c|c|c|c|c|c|c|c|c|}
\hline & & Prihodi & Rashodi & $\begin{array}{c}\text { Suficit } \\
\text { ili } \\
\text { deficit }\end{array}$ & $\begin{array}{c}\text { Broj } \\
\text { stanov- } \\
\text { nika }\end{array}$ & Prihodi & Rashodi & $\begin{array}{c}\text { Suficit } \\
\text { ili } \\
\text { deficit }\end{array}$ & $\begin{array}{c}\text { Razina } \\
\text { trans- } \\
\text { parent- } \\
\text { nosti }\end{array}$ \\
\hline 323. & Velika Trnovitica & 1.500 & 1.358 & 143 & 1.370 & 2,1 & 1,9 & 0,2 & 0 \\
\hline 324. & Bedekovčina & 1.497 & 1.261 & 236 & 8.041 & 12,0 & 10,1 & 1,9 & 3 \\
\hline 325. & Garčin & 1.485 & 1.543 & -58 & 4.806 & 7,1 & 7,4 & $-0,3$ & 1 \\
\hline 326. & Žakanje & 1.471 & 1.287 & 185 & 1.889 & 2,8 & 2,4 & 0,3 & 1 \\
\hline 327. & Beretinec & 1.467 & 1.436 & 31 & 2.176 & 3,2 & 3,1 & 0,1 & 3 \\
\hline 328. & Đulovac & 1.463 & 1.275 & 188 & 3.245 & 4,7 & 4,1 & 0,6 & 1 \\
\hline 329. & Vinica & 1.461 & 1.396 & 65 & 3.389 & 5,0 & 4,7 & 0,2 & 0 \\
\hline 330. & Trnava & 1.447 & 2.410 & -963 & 1.600 & 2,3 & 3,9 & $-1,5$ & 0 \\
\hline 331. & $\begin{array}{l}\text { Sveti Martin } \\
\text { na Muri }\end{array}$ & 1.441 & 1.434 & 6 & 2.605 & 3,8 & 3,7 & 0,0 & 2 \\
\hline 332. & Hercegovac & 1.441 & 1.445 & -4 & 2.383 & 3,4 & 3,4 & 0,0 & 3 \\
\hline 333. & Cernik & 1.428 & 1.347 & 81 & 3.640 & 5,2 & 4,9 & 0,3 & 3 \\
\hline 334. & Dvor & 1.422 & 1.287 & 135 & 5.570 & 7,9 & 7,2 & 0,8 & 2 \\
\hline 335. & Gorjani & 1.421 & 1.176 & 246 & 1.591 & 2,3 & 1,9 & 0,4 & 0 \\
\hline 336. & Sunja & 1.414 & 1.248 & 166 & 5.748 & 8,1 & 7,2 & 1,0 & 1 \\
\hline 337. & Galovac & 1.412 & 1.199 & 213 & 1.234 & 1,7 & 1,5 & 0,3 & 0 \\
\hline 338. & Velika Kopanica & 1.410 & 1.482 & -72 & 3.308 & 4,7 & 4,9 & $-0,2$ & 1 \\
\hline 339. & Klenovnik & 1.409 & 1.783 & -374 & 2.022 & 2,8 & 3,6 & $-0,8$ & 0 \\
\hline 340. & Vrpolje & 1.400 & 1.371 & 29 & 3.521 & 4,9 & 4,8 & 0,1 & 0 \\
\hline 341. & Okučani & 1.396 & 1.432 & -35 & 3.447 & 4,8 & 4,9 & $-0,1$ & 1 \\
\hline 342. & Sveta Marija & 1.395 & 1.303 & 92 & 2.317 & 3,2 & 3,0 & 0,2 & 1 \\
\hline 343. & Petrijanec & 1.383 & 1.179 & 204 & 4.812 & 6,7 & 5,7 & 1,0 & 0 \\
\hline 344. & Donji Vidovec & 1.381 & 1.344 & 37 & 1.399 & 1,9 & 1,9 & 0,1 & 0 \\
\hline 345. & Podcrkavlje & 1.379 & 1.283 & 96 & 2.553 & 3,5 & 3,3 & 0,2 & 2 \\
\hline 346. & Bošnjaci & 1.372 & 1.351 & 21 & 3.901 & 5,4 & 5,3 & 0,1 & 0 \\
\hline 347. & Mali Bukovec & 1.367 & 1.258 & 109 & 2.212 & 3,0 & 2,8 & 0,2 & 3 \\
\hline 348. & Koška & 1.365 & 1.280 & 85 & 3.980 & 5,4 & 5,1 & 0,3 & 1 \\
\hline 349. & Viškovci & 1.361 & 1.265 & 95 & 1.906 & 2,6 & 2,4 & 0,2 & 0 \\
\hline 350. & Trpinja & 1.358 & 1.329 & 29 & 5.572 & 7,6 & 7,4 & 0,2 & 0 \\
\hline 351. & Rakovec & 1.353 & 1.158 & 195 & 1.252 & 1,7 & 1,5 & 0,2 & 3 \\
\hline 352. & Vrbje & 1.353 & 1.088 & 265 & 2.215 & 3,0 & 2,4 & 0,6 & 0 \\
\hline 353. & Feričanci & 1.352 & 1.299 & 53 & 2.134 & 2,9 & 2,8 & 0,1 & 3 \\
\hline 354. & Donji Kukuruzari & 1.347 & 1.404 & -57 & 1.634 & 2,2 & 2,3 & $-0,1$ & 3 \\
\hline 355. & Donji Kraljevec & 1.340 & 1.187 & 153 & 4.659 & 6,2 & 5,5 & 0,7 & 3 \\
\hline 356. & Pribislavec & 1.331 & 1.387 & -56 & 3.136 & 4,2 & 4,4 & $-0,2$ & 1 \\
\hline 357. & Mikleuš & 1.329 & 1.315 & 14 & 1.464 & 1,9 & 1,9 & 0,0 & 2 \\
\hline 358. & Sračinec & 1.327 & 1.234 & 93 & 4.842 & 6,4 & 6,0 & 0,4 & 2 \\
\hline 359. & Andrijaševci & 1.311 & 1.143 & 168 & 4.075 & 5,3 & 4,7 & 0,7 & 3 \\
\hline 360. & Nova Rača & 1.306 & 1.163 & 142 & 3.433 & 4,5 & 4,0 & 0,5 & 2 \\
\hline 361. & Kotoriba & 1.290 & 1.203 & 87 & 3.224 & 4,2 & 3,9 & 0,3 & 3 \\
\hline 362. & Domašinec & 1.287 & 982 & 305 & 2.251 & 2,9 & 2,2 & 0,7 & 1 \\
\hline 363. & Dežanovac & 1.287 & 1.795 & -508 & 2.715 & 3,5 & 4,9 & $-1,4$ & 0 \\
\hline 364. & Runovići & 1.286 & 1.421 & -135 & 2.416 & 3,1 & 3,4 & $-0,3$ & 1 \\
\hline 365. & Čepin & 1.286 & 1.166 & 120 & 11.599 & 14,9 & 13,5 & 1,4 & 0 \\
\hline 366. & Donji Andrijevci & 1.282 & 1.117 & 164 & 3.709 & 4,8 & 4,1 & 0,6 & 1 \\
\hline 367. & Kloštar Podravski & 1.280 & 1.375 & -96 & 3.306 & 4,2 & 4,5 & $-0,3$ & 0 \\
\hline 368. & Slavonski Šamac & 1.279 & 1.208 & 70 & 2.169 & 2,8 & 2,6 & 0,2 & 2 \\
\hline 369. & Brodski Stupnik & 1.278 & 1.576 & -298 & 3.036 & 3,9 & 4,8 & $-0,9$ & 1 \\
\hline 370. & Krašić & 1.274 & 1.279 & -5 & 2.640 & 3,4 & 3,4 & 0,0 & 3 \\
\hline 371. & Stari Mikanovci & 1.260 & 1.251 & 9 & 2.956 & 3,7 & 3,7 & 0,0 & 2 \\
\hline 372. & Sveti Đurđ & 1.257 & 1.367 & -110 & 3.804 & 4,8 & 5,2 & $-0,4$ & 1 \\
\hline 373. & Belica & 1.245 & 1.167 & 78 & 3.176 & 4,0 & 3,7 & 0,2 & 4 \\
\hline 374. & Špišić Bukovica & 1.243 & 1.228 & 15 & 4.221 & 5,2 & 5,2 & 0,1 & 0 \\
\hline 375. & Kaptol & 1.240 & 1.283 & -43 & 3.472 & 4,3 & 4,5 & $-0,1$ & 0 \\
\hline 376. & Đelekovec & 1.240 & 1.200 & 41 & 1.533 & 1,9 & 1,8 & 0,1 & 2 \\
\hline 377. & Gradec & 1.208 & 1.206 & 2 & 3.681 & 4,4 & 4,4 & 0,0 & 0 \\
\hline
\end{tabular}

NEWSLETTER 98 | KATARINA OTT i MIHAELA BRONIĆ | Ostvarenje proračuna općina, gradova i... | Institut za javne financije 9 
Po stanovniku, u kunama

Ukupno, u mil. kuna

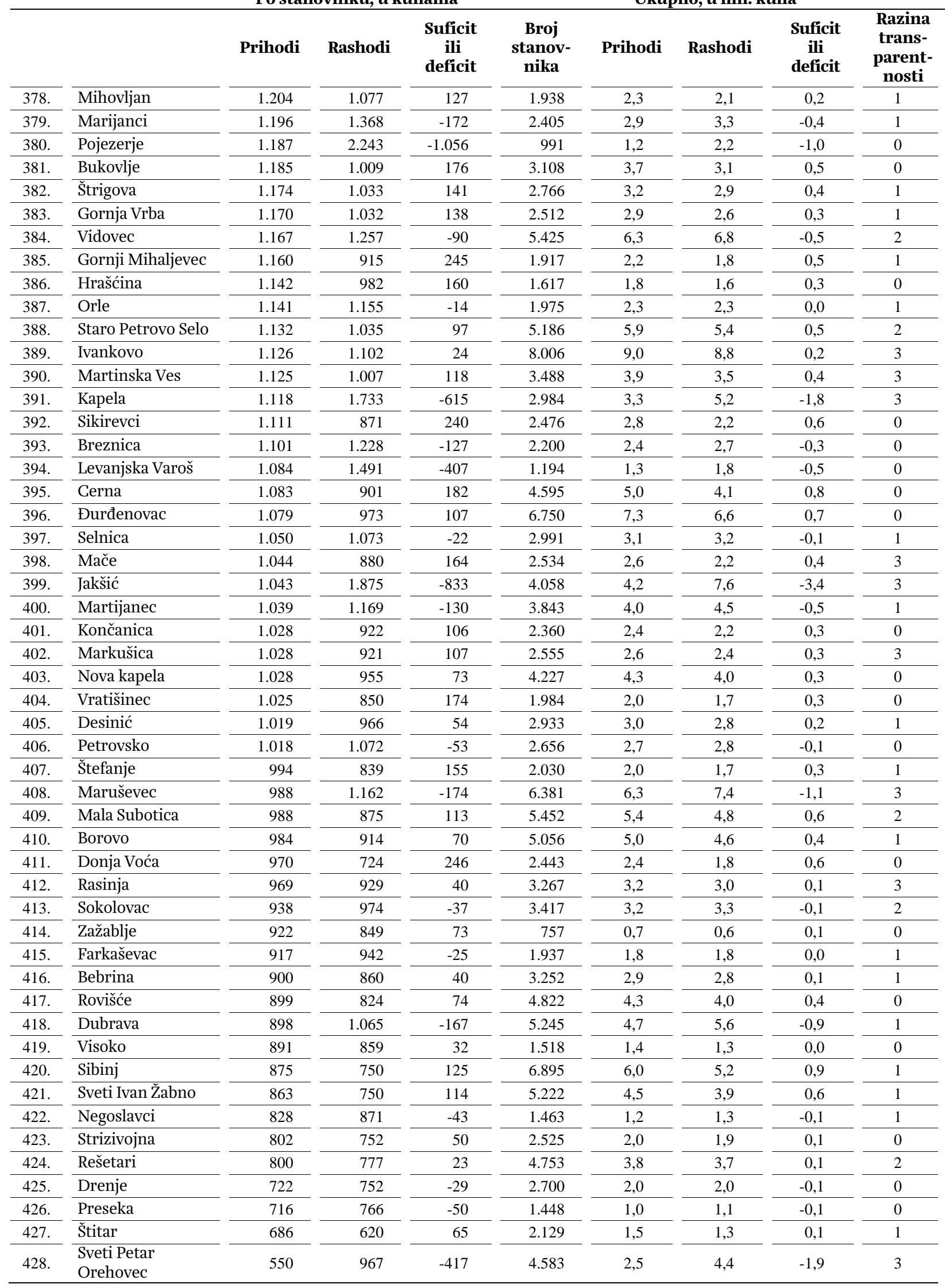

Izvor: Autorice na temelju Ministarstva financija (2015), DZS (20I5) te Ott, Bronić i Petrušić (2015).

IO NEWSLETTER 98 | KATARINA OTT i MIHAELA BRONIĆ | Ostvarenje proračuna općina, gradova i... | Institut za javne financije 
Tabela 2.

Ostvarenje proračuna gradova u 2014.

Po stanovniku, u kunama

Ukupno, u mil. kuna

\begin{tabular}{|c|c|c|c|c|c|c|c|c|c|}
\hline & & Prihodi & Rashodi & $\begin{array}{c}\text { Suficit } \\
\text { ili } \\
\text { deficit }\end{array}$ & $\begin{array}{c}\text { Broj } \\
\text { stanov- } \\
\text { nika }\end{array}$ & Prihodi & Rashodi & $\begin{array}{c}\text { Suficit } \\
\text { ili } \\
\text { deficit }\end{array}$ & $\begin{array}{c}\text { Razina } \\
\text { trans- } \\
\text { parent- } \\
\text { nosti } \\
\end{array}$ \\
\hline 1. & Novalja & 11.659 & 11.252 & 407 & 3.663 & 43 & 41 & 1 & 3 \\
\hline 2. & Vis & 10.534 & 9.741 & 793 & 1.934 & 20 & 19 & 2 & 2 \\
\hline 3. & Vrlika & 10.466 & 10.203 & 264 & 2.177 & 23 & 22 & 1 & 1 \\
\hline 4. & Krk & 10.450 & 9.403 & 1.047 & 6.281 & 66 & 59 & 7 & 4 \\
\hline 5. & Rovinj & 9.976 & 8.016 & 1.960 & 14.294 & 143 & 115 & 28 & 1 \\
\hline 6. & Opatija & 9.920 & 10.295 & -375 & 11.659 & 116 & 120 & -4 & 5 \\
\hline 7. & Poreč & 9.395 & 6.923 & 2.471 & 16.696 & 157 & 116 & 41 & 4 \\
\hline 8. & Supetar & 8.908 & 6.477 & 2.430 & 4.074 & 36 & 26 & 10 & 1 \\
\hline 9. & Novigrad (Istra) & 8.900 & 8.519 & 381 & 4.345 & 39 & 37 & 2 & 4 \\
\hline 10. & Dubrovnik & 8.807 & 9.137 & -330 & 42.615 & 375 & 389 & -14 & 5 \\
\hline 11. & Zagreb & 8.418 & 9.662 & -1.244 & 790.017 & 6.651 & 7.633 & -983 & 5 \\
\hline 12. & Mali Lošinj & 8.208 & 8.256 & -48 & 8.116 & 67 & 67 & 0 & 3 \\
\hline 13. & Umag & 8.088 & 7.681 & 408 & 13.467 & 109 & 103 & 5 & 4 \\
\hline 14. & Hvar & 7.987 & 8.689 & -702 & 4.251 & 34 & 37 & -3 & 3 \\
\hline 15. & Cres & 7.740 & 7.940 & -200 & 2.879 & 22 & 23 & -1 & 4 \\
\hline 16. & Biograd na moru & 7.302 & 7.173 & 129 & 5.569 & 41 & 40 & 1 & 2 \\
\hline 17. & Nin & 7.049 & 6.788 & 261 & 2.744 & 19 & 19 & 1 & 0 \\
\hline 18. & Lipik & 7.009 & 6.171 & 839 & 6.170 & 43 & 38 & 5 & 4 \\
\hline 19. & Pazin & 6.944 & 8.504 & -1.560 & 8.638 & 60 & 73 & -13 & 5 \\
\hline 20. & Crikvenica & 6.914 & 5.143 & 1.771 & 11.122 & 77 & 57 & 20 & 5 \\
\hline 21. & Buzet & 6.321 & 5.858 & 463 & 6.133 & 39 & 36 & 3 & 5 \\
\hline 22. & Stari Grad & 6.242 & 6.781 & -539 & 2.781 & 17 & 19 & -1 & 0 \\
\hline 23. & Vodnjan & 6.238 & 6.529 & -292 & 6.119 & 38 & 40 & -2 & 1 \\
\hline 24. & Korčula & 6.143 & 5.999 & 144 & 5.663 & 35 & 34 & 1 & 3 \\
\hline 25. & Pakrac & 5.894 & 5.348 & 546 & 8.460 & 50 & 45 & 5 & 3 \\
\hline 26. & Bakar & 5.826 & 5.421 & 404 & 8.279 & 48 & 45 & 3 & 3 \\
\hline 27. & Labin & 5.790 & 5.534 & 257 & 11.642 & 67 & 64 & 3 & 4 \\
\hline 28. & Novi Vinodolski & 5.583 & 5.248 & 335 & 5.113 & 29 & 27 & 2 & 3 \\
\hline 29. & Senj & 5.469 & 3.639 & 1.830 & 7.182 & 39 & 26 & 13 & 3 \\
\hline 30. & Vodice & 5.459 & 4.467 & 991 & 8.875 & 48 & 40 & 9 & 5 \\
\hline 31. & Gospić & 5.322 & 5.252 & 70 & 12.745 & 68 & 67 & 1 & 0 \\
\hline 32. & Pag & 5.282 & 4.594 & 688 & 3.846 & 20 & 18 & 3 & 0 \\
\hline 33. & Rijeka & 5.230 & 4.919 & 312 & 128.624 & 673 & 633 & 40 & 5 \\
\hline 34. & Sveta Nedjelja & 5.093 & 3.752 & 1.341 & 18.059 & 92 & 68 & 24 & 4 \\
\hline 35. & Zaprešić & 4.924 & 4.412 & 513 & 25.223 & 124 & 111 & 13 & 4 \\
\hline 36. & Delnice & 4.906 & 5.253 & -346 & 5.952 & 29 & 31 & -2 & 3 \\
\hline 37. & Pula & 4.875 & 4.799 & 76 & 57.460 & 280 & 276 & 4 & 5 \\
\hline 38. & Makarska & 4.863 & 4.397 & 466 & 13.834 & 67 & 61 & 6 & 3 \\
\hline 39. & Vukovar & 4.763 & 3.447 & 1.316 & 27.683 & 132 & 95 & 36 & 4 \\
\hline 40. & Varaždin & 4.685 & 4.645 & 40 & 46.946 & 220 & 218 & 2 & 4 \\
\hline 41. & Zadar & 4.676 & 4.534 & 142 & 75.062 & 351 & 340 & 11 & 4 \\
\hline 42. & Komiža & 4.606 & 4.090 & 516 & 1.526 & 7 & 6 & 1 & 3 \\
\hline 43. & Samobor & 4.513 & 3.979 & 533 & 37.633 & 170 & 150 & 20 & 2 \\
\hline 44. & Rab & 4.370 & 5.231 & -861 & 8.065 & 35 & 42 & -7 & 1 \\
\hline 45. & Trogir & 4.174 & 3.649 & 525 & 13.192 & 55 & 48 & 7 & 3 \\
\hline 46. & Buje & 4.135 & 4.400 & -265 & 5.182 & 21 & 23 & -1 & 4 \\
\hline 47. & Split & 4.095 & 3.990 & 105 & 178.102 & 729 & 711 & 19 & 5 \\
\hline 48. & Šibenik & 3.967 & 4.278 & -310 & 46.332 & 184 & 198 & -14 & 5 \\
\hline 49. & Orahovica & 3.950 & 2.885 & 1.065 & 5.304 & 21 & 15 & 6 & 3 \\
\hline 50. & Zabok & 3.929 & 3.827 & 103 & 8.994 & 35 & 34 & 1 & 2 \\
\hline 51. & Obrovac & 3.913 & 4.096 & -184 & 4.323 & 17 & 18 & -1 & 1 \\
\hline 52. & Virovitica & 3.895 & 3.295 & 600 & 21.291 & 83 & 70 & 13 & 3 \\
\hline 53. & Koprivnica & 3.817 & 4.453 & -636 & 30.854 & 118 & 137 & -20 & 5 \\
\hline
\end{tabular}

NEWSLETTER 98 | KATARINA OTT i MIHAELA BRONIĆ | Ostvarenje proračuna općina, gradova i... | Institut za javne financije II 
Po stanovniku, u kunama

Ukupno, u mil. kuna

\begin{tabular}{|c|c|c|c|c|c|c|c|c|c|}
\hline & & Prihodi & Rashodi & $\begin{array}{l}\text { Suficit } \\
\text { ili } \\
\text { deficit }\end{array}$ & $\begin{array}{c}\text { Broj } \\
\text { stanov- } \\
\text { nika }\end{array}$ & Prihodi & Rashodi & $\begin{array}{l}\text { Suficit } \\
\text { ili } \\
\text { deficit }\end{array}$ & $\begin{array}{c}\text { Razina } \\
\text { trans- } \\
\text { parent- } \\
\text { nosti }\end{array}$ \\
\hline 54. & Karlovac & 3.782 & 4.059 & -277 & 55.705 & 211 & 226 & -15 & 4 \\
\hline 55. & Čakovec & 3.762 & 3.636 & 126 & 27.104 & 102 & 99 & 3 & 5 \\
\hline 56. & Slunj & 3.694 & 3.557 & 138 & 5.076 & 19 & 18 & 1 & 4 \\
\hline 57. & Belišće & 3.627 & 5.029 & -1.401 & 10.825 & 39 & 54 & -15 & 0 \\
\hline 58. & Velika Gorica & 3.619 & 3.901 & -282 & 63.517 & 230 & 248 & -18 & 4 \\
\hline 59. & Čabar & 3.595 & 4.139 & -544 & 3.770 & 14 & 16 & -2 & 3 \\
\hline 60. & Vrbovsko & 3.592 & 3.288 & 305 & 5.076 & 18 & 17 & 2 & 1 \\
\hline 61. & Osijek & 3.540 & 3.546 & -6 & 108.048 & 382 & 383 & -1 & 5 \\
\hline 62. & Sisak & 3.517 & 3.471 & 46 & 47.768 & 168 & 166 & 2 & 0 \\
\hline 63. & Ivanić-Grad & 3.454 & 3.087 & 366 & 14.548 & 50 & 45 & 5 & 4 \\
\hline 64. & Kutina & 3.450 & 3.121 & 329 & 22.760 & 79 & 71 & 7 & 2 \\
\hline 65. & Solin & 3.447 & 3.657 & -210 & 23.926 & 82 & 88 & -5 & 3 \\
\hline 66. & Beli Manastir & 3.430 & 3.290 & 140 & 10.068 & 35 & 33 & 1 & 0 \\
\hline 67. & Omiš & 3.411 & 3.746 & -336 & 14.936 & 51 & 56 & -5 & 4 \\
\hline 68. & Đurđevac & 3.312 & 2.948 & 364 & 8.264 & 27 & 24 & 3 & 0 \\
\hline 69. & Kraljevica & 3.231 & 3.235 & -4 & 4.618 & 15 & 15 & 0 & 4 \\
\hline 70. & Kastav & 3.006 & 2.742 & 264 & 10.440 & 31 & 29 & 3 & 3 \\
\hline 71. & Drniš & 2.984 & 3.623 & -639 & 7.498 & 22 & 27 & -5 & 4 \\
\hline 72. & Križevci & 2.934 & 2.705 & 229 & 21.122 & 62 & 57 & 5 & 2 \\
\hline 73. & Donja Stubica & 2.844 & 2.853 & -9 & 5.680 & 16 & 16 & 0 & 3 \\
\hline 74. & Jastrebarsko & 2.839 & 3.610 & -771 & 15.866 & 45 & 57 & -12 & 4 \\
\hline 75. & Ogulin & 2.833 & 2.715 & 118 & 13.915 & 39 & 38 & 2 & 4 \\
\hline 76. & Skradin & 2.828 & 3.884 & -1.056 & 3.825 & 11 & 15 & -4 & 1 \\
\hline 77. & Petrinja & 2.799 & 2.912 & -113 & 24.671 & 69 & 72 & -3 & 0 \\
\hline 78. & Otočac & 2.767 & 2.071 & 697 & 9.778 & 27 & 20 & 7 & 0 \\
\hline 79. & Kaštela & 2.764 & 2.637 & 127 & 38.667 & 107 & 102 & 5 & 4 \\
\hline 80. & Vinkovci & 2.756 & 2.766 & -11 & 35.312 & 97 & 98 & 0 & 0 \\
\hline 81. & Požega & 2.749 & 2.603 & 146 & 26.248 & 72 & 68 & 4 & 1 \\
\hline 82. & Bjelovar & 2.691 & 2.706 & -15 & 40.276 & 108 & 109 & -1 & 4 \\
\hline 83. & Glina & 2.683 & 2.209 & 474 & 9.283 & 25 & 21 & 4 & 4 \\
\hline 84. & Novska & 2.658 & 2.598 & 60 & 13.518 & 36 & 35 & 1 & 4 \\
\hline 85. & Županja & 2.647 & 2.479 & 168 & 12.090 & 32 & 30 & 2 & 4 \\
\hline 86. & Ilok & 2.625 & 2.083 & 542 & 6.767 & 18 & 14 & 4 & 2 \\
\hline 87. & Ludbreg & 2.590 & 2.517 & 73 & 8.478 & 22 & 21 & 1 & 4 \\
\hline 88. & Imotski & 2.588 & 2.717 & -129 & 10.764 & 28 & 29 & -1 & 1 \\
\hline 89. & Popovača & 2.553 & 3.028 & -475 & 11.905 & 30 & 36 & -6 & 2 \\
\hline 90. & $\begin{array}{l}\text { Hrvatska } \\
\text { Kostajnica }\end{array}$ & 2.549 & 1.930 & 619 & 2.756 & 7 & 5 & 2 & 3 \\
\hline 91. & Prelog & 2.527 & 2.890 & -363 & 7.815 & 20 & 23 & -3 & 4 \\
\hline 92. & Lepoglava & 2.520 & 2.475 & 45 & 8.283 & 21 & 21 & 0 & 4 \\
\hline 93. & Našice & 2.515 & 2.182 & 332 & 16.224 & 41 & 35 & 5 & 4 \\
\hline 94. & Klanjec & 2.495 & 2.081 & 414 & 2.915 & 7 & 6 & 1 & 1 \\
\hline 95. & Vrgorac & 2.482 & 2.869 & -387 & 6.572 & 16 & 19 & -3 & 0 \\
\hline 96. & Grubišno Polje & 2.465 & 3.284 & -819 & 6.478 & 16 & 21 & -5 & 1 \\
\hline 97. & Opuzen & 2.461 & 2.937 & -477 & 3.254 & 8 & 10 & -2 & 2 \\
\hline 98. & Benkovac & 2.449 & 2.165 & 284 & 11.026 & 27 & 24 & 3 & 3 \\
\hline 99. & Krapina & 2.420 & 2.304 & 116 & 12.480 & 30 & 29 & 1 & 4 \\
\hline 100. & Knin & 2.406 & 2.246 & 160 & 15.407 & 37 & 35 & 2 & 1 \\
\hline 101. & Dugo Selo & 2.397 & 2.317 & 79 & 17.466 & 42 & 40 & 1 & 3 \\
\hline 102. & Daruvar & 2.385 & 2.239 & 146 & 11.633 & 28 & 26 & 2 & 3 \\
\hline 103. & Vrbovec & 2.327 & 2.331 & -4 & 14.797 & 34 & 34 & 0 & 3 \\
\hline 104. & Slatina & 2.307 & 2.117 & 190 & 13.686 & 32 & 29 & 3 & 3 \\
\hline 105. & Slavonski Brod & 2.245 & 1.870 & 375 & 59.141 & 133 & 111 & 22 & 5 \\
\hline 106. & Sinj & 2.222 & 2.110 & 112 & 24.826 & 55 & 52 & 3 & 1 \\
\hline 107. & Ozalj & 2.180 & 2.301 & -121 & 6.817 & 15 & 16 & -1 & 3 \\
\hline 108. & Ploče & 2.164 & 2.725 & -561 & 10.135 & 22 & 28 & -6 & 3 \\
\hline
\end{tabular}


Po stanovniku, u kunama

Ukupno, u mil. kuna

\begin{tabular}{|c|c|c|c|c|c|c|c|c|c|}
\hline & & & \\
\hline & & Prihodi & Rashodi & $\begin{array}{c}\text { Suficit } \\
\text { ili } \\
\text { deficit }\end{array}$ & $\begin{array}{c}\text { Broj } \\
\text { stanov- } \\
\text { nika }\end{array}$ & Prihodi & Rashodi & $\begin{array}{l}\text { Suficit } \\
\text { ili } \\
\text { deficit }\end{array}$ & $\begin{array}{c}\text { Razina } \\
\text { trans- } \\
\text { parent- } \\
\text { nosti }\end{array}$ \\
\hline 109. & Nova Gradiška & 2.151 & 2.106 & 45 & 14.229 & 31 & 30 & 1 & 0 \\
\hline 110. & Otok (Vinkovci) & 2.124 & 1.788 & 336 & 6.343 & 13 & 11 & 2 & 0 \\
\hline 111. & Oroslavje & 2.072 & 1.983 & 89 & 6.138 & 13 & 12 & 1 & 2 \\
\hline 112. & Duga Resa & 2.039 & 2.193 & -154 & 11.180 & 23 & 25 & -2 & 4 \\
\hline 113. & Pleternica & 2.032 & 1.905 & 127 & 11.323 & 23 & 22 & 1 & 0 \\
\hline 114. & Čazma & 1.999 & 1.892 & 108 & 8.077 & 16 & 15 & 1 & 3 \\
\hline 115. & Sveti Ivan Zelina & 1.987 & 2.052 & -65 & 15.959 & 32 & 33 & -1 & 0 \\
\hline 116. & Donji Miholjac & 1.944 & 1.697 & 248 & 9.491 & 18 & 16 & 2 & 3 \\
\hline 117. & Trilj & 1.913 & 1.864 & 48 & 9.109 & 17 & 17 & 0 & 0 \\
\hline 118. & Zlatar & 1.850 & 1.255 & 594 & 6.096 & 11 & 8 & 4 & 4 \\
\hline 119. & Ivanec & 1.844 & 1.619 & 225 & 13.758 & 25 & 22 & 3 & 3 \\
\hline 120. & Pregrada & 1.829 & 1.832 & -4 & 6.594 & 12 & 12 & 0 & 4 \\
\hline 121. & Garešnica & 1.798 & 1.687 & 110 & 10.472 & 19 & 18 & 1 & 1 \\
\hline 122. & $\begin{array}{l}\text { Varaždinske } \\
\text { Toplice }\end{array}$ & 1.770 & 1.771 & -1 & 6.364 & 11 & 11 & 0 & 3 \\
\hline 123. & Valpovo & 1.742 & 1.741 & 1 & 11.563 & 20 & 20 & 0 & 2 \\
\hline 124. & Metković & 1.693 & 1.560 & 133 & 16.788 & 28 & 26 & 2 & 2 \\
\hline 125. & Mursko Središće & 1.593 & 1.487 & 106 & 6.307 & 10 & 9 & 1 & 1 \\
\hline 126. & Đakovo & 1.428 & 1.347 & 81 & 27.745 & 40 & 37 & 2 & 1 \\
\hline 127. & Kutjevo & 1.336 & 1.323 & 13 & 6.247 & 8 & 8 & 0 & 0 \\
\hline 128. & Novi Marof & 1.319 & 1.210 & 109 & 13.246 & 17 & 16 & 1 & 2 \\
\hline
\end{tabular}

Izvor: Autorice na temelju Ministarstva financija (20I5), DZS (20I5) te Ott, Bronić i Petrušić (20I5).

Tabela 3.

Ostvarenje proračuna županija u 2014.

Po stanovniku, u kunama

Ukupno, u mil. kuna

\begin{tabular}{|c|c|c|c|c|c|c|c|c|c|}
\hline & & Prihodi & Rashodi & $\begin{array}{l}\text { Suficit } \\
\text { ili } \\
\text { deficit }\end{array}$ & $\begin{array}{c}\text { Broj } \\
\text { stanov- } \\
\text { nika }\end{array}$ & Prihodi & Rashodi & $\begin{array}{l}\text { Suficit } \\
\text { ili } \\
\text { deficit }\end{array}$ & $\begin{array}{c}\text { Razina } \\
\text { trans- } \\
\text { parent- } \\
\text { nosti }\end{array}$ \\
\hline 1. & Virovitičko-podravska & 1.436 & 1.363 & 72 & 84.836 & 122 & 116 & 6 & 3 \\
\hline 2. & Istarska & 1.353 & 1.250 & 102 & 208.055 & 281 & 260 & 21 & 4 \\
\hline 3. & $\begin{array}{l}\text { Koprivničko- } \\
\text { križevačka }\end{array}$ & 1.269 & 1.223 & 46 & 115.584 & 147 & 141 & 5 & 4 \\
\hline 4. & Varaždinska & 1.250 & 1.124 & 126 & 175.951 & 220 & 198 & 22 & 5 \\
\hline 5. & Ličko-senjska & 1.191 & 1.179 & 12 & 50.927 & 61 & 60 & 1 & 4 \\
\hline 6. & Šibensko-kninska & 1.152 & 1.143 & 8 & 109.375 & 126 & 125 & 1 & 5 \\
\hline 7. & $\begin{array}{l}\text { Dubrvačko- } \\
\text { neretvanska }\end{array}$ & 1.147 & 1.085 & 62 & 122.568 & 141 & 133 & 8 & 4 \\
\hline 8. & Karlovačka & 1.147 & 1.155 & -9 & 128.899 & 148 & 149 & -1 & 4 \\
\hline 9. & Zadarska & 1.126 & 1.065 & 62 & 170.017 & 191 & 181 & 10 & 5 \\
\hline 10. & Krapinsko-zagorska & 1.100 & 1.096 & 4 & 132.892 & 146 & 146 & 1 & 5 \\
\hline 11. & Požeško-slavonska & 1.089 & 1.017 & 72 & 78.034 & 85 & 79 & 6 & 3 \\
\hline 12. & Primorsko-goranska & 1.058 & 1.002 & 57 & 296.195 & 313 & 297 & 17 & 4 \\
\hline 13. & Brodsko-posavska & 1.033 & 1.029 & 4 & 158.575 & 164 & 163 & 1 & 5 \\
\hline 14. & Međimurska & 1.026 & 1.032 & -6 & 113.804 & 117 & 117 & -1 & 3 \\
\hline 15. & $\begin{array}{l}\text { Bjelovarsko- } \\
\text { bilogorska }\end{array}$ & 996 & 942 & 53 & 119.764 & 119 & 113 & 6 & 4 \\
\hline 16. & Vukovarsko-srijemska & 988 & 924 & 64 & 179.521 & 177 & 166 & 12 & 3 \\
\hline 17. & Osječko-baranjska & 958 & 937 & 21 & 305.032 & 292 & 286 & 7 & 4 \\
\hline 18. & Splitsko-dalmatinska & 954 & 945 & 9 & 454.798 & 434 & 430 & 4 & 3 \\
\hline 19. & Sisačko-moslovačka & 946 & 995 & -49 & 172.439 & 163 & 172 & -9 & 2 \\
\hline 20. & Zagrebačka & 912 & 886 & 26 & 317.606 & 290 & 282 & 8 & 4 \\
\hline
\end{tabular}

Izvor: Autorice na temelju Ministarstva financija (2015), DZS (20I5) te Ott, Bronić i Petrušić (2015).

NEWSLETTER 98 ｜ KATARINA OTT i MIHAELA BRONIĆ | Ostvarenje proračuna općina, gradova i... | Institut za javne financije I3 


\section{LITERATURA}

Bajo, A. i Primorac, M., 20I4. Dug i fiskalni rizici jedinica lokalne i područne (regionalne) samouprave. Newsletter, br. 93.

DZS, 20I5. Popis stanovništva, kućanstava i stanova 20II. godine. Zagreb: Državni zavod za statistiku.

IJF, 2015. Otvorenost lokalnih proračuna. Zagreb: Institut za javne financije.

Ministarstvo financija, 2015. Lokalni proračuni - arhiva. Zagreb: Ministarstvo financija.

Ott, K., Bronić, M. i Petrušić, M., 2015. Otvorenost proračuna županija, gradova i općina: studeni 20I4. ožujak 2015. Newsletter, br. 97.

Zakon o proračunu, NN 87/o8, I36/12, I5/15. Zagreb: Narodne novine.

I4 NEWSLETTER 98 | KATARINA OTT i MIHAELA BRONIĆ | Ostvarenje proračuna općina, gradova i... | Institut za javne financije 